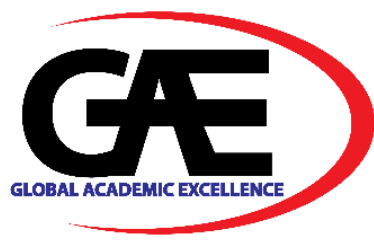

\title{
THE INFLUENCE OF POLITICAL IDENTITY TOWARDS TOLERANCE PEOPLES IN PEMATANGSIANTAR CITY DURING THE GOVERNORS SUMATERA UTARA ELECTION IN 2018
}

\author{
Adil Arifin ${ }^{1 *}$, Fajar Utama Ritonga ${ }^{2}$ \\ 1 Political Sciences Department, Faculty of Social and Political Sciences, Universitas Sumatera Utara, Medan. \\ Indonesia. \\ Email: rifin83@yahoo.com \\ 2 Social Welfare Program Study, Faculty of Social and Political Sciences, Universitas Sumatera Utara, Medan. \\ Indonesia \\ Email: fajar.utama@usu.ac.id \\ Corresponding Author
}

Article Info:

\section{Article history:}

Received date: 20.01 .2021

Revised date: 28.02 .2021

Accepted date: 18.03.2021

Published date: 31.03 .2021

\section{To cite this document:}

Arifin, A., Ritonga, F. U. (2021). The Influence of Political Identity Towards Tolerance Peoples in Pematangsiantar City During The Governors Sumatera Utara Election in 2018. International Journal of Law, Government and Communication, 6 (22), 238-252.

DOI: $10.35631 /$ IJLGC.6220023.

This work is licensed under CC BY 4.0

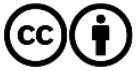

Abstract:

The purpose of this study is to measure how much is influence political identity has on the tolerance of the people of Pematangsiantar City in the Governor Election of Sumatera Utara Province of 2018. The research method uses a quantitative approach with a correlation approach, the population in this study is Pematangsiantar City who is registered in the 2018 Daftar Pemilih Tetap (DPT), the research sample uses a 5\% margin so that a sample of 399 people was obtained. The sampling technique used a proportional multistage random sampling spread over the research locations, namely 8 districts and 53 sub-districts in Pematangsiantar City. The data collection technique uses a research questionnaire that has been tested for its validity and reliability. data analysis technique using Rank Spearman. The results show the correlation between the political identity variable and the tolerance of peoples in Pematangsiantar City in the 2018 Sumatra Utara governor election is $(-0.120)$ which means very weak, negative, significant, and a twoway significance value or sig (2-tailed) of 0.017 because the number of significance is $0.017<0.05$. This illustrates that political identity has a weak influence on the tolerance of the Pematangsiantar City community in social life, if political identity is high, then the social tolerance of the community will be low (intolerance still occurs in differences in choice due to politics of identity/ethnicity, religion, and regional origin), however, if identity politics is low in the 2018 Sumatera Utara governor election, then social tolerance will be high. In conclusion, the people of Pematangsiantar City, which is known as "Tolerant City", cannot be separated from the influence of political identity in the 2018 Sumatra Utara Governor Election. 


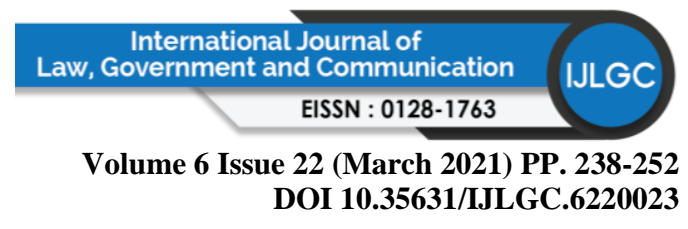

Keywords:

Politic Identity, Tolerance, Pematangsiantar City

\section{Introduction}

The Sumatera Utara Governor's Election in 2018 was held and the fighting pair was Edy Rahmayadi and Musa Rajeksah against the Djarot Saiful Hidayat and Sihar Sitorus. Political Identity still feels strong in North Sumatera after the local political battle for the 2017 DKI Jakarta Governor Election, this is exacerbated by one of the candidates for Governor of North Sumatra in 2018, Djarot Saiful Hidayat, who was Ahok's running mate during the 2017 DKI Jakarta Governor's Election. avoided the constellation of National Politics (because Jakarta is the capital of the Republic of Indonesia) and Local Politics throughout Indonesia which are still thick with political identity, which is inevitable, including the 2018 North Sumatra Governor's Election.

Strengthening political identity and political representation automatically appears as a result of the opening of the tap of political participation, which began in the reform era until now (Ana Sabhana and Suryani, 2016: 21). In this case, it seems as if there is a struggle between indigenous and non-indigenous people. The Jakarta Pilkada in 2017 which was won by Anis Baswedan and Sandiaga Uno became a new portrait for the struggle for political identity and political representation in Indonesia where at that time the opponent was Ahok-Djarot in the second round of elections. In this case, Ahok-Djarot became a portrait of identity and a nonMuslim representation of ethnic Chinese and Anis-Sandi became a representation of indigenous Muslims. (Nasrudin, 2018).

A massive wave of Muslim protests seemed to demand the government to immediately decide "what Ahok did was blasphemy". The decision of the MUI's fatwa through Maruf Amin regarding the blasphemy committed by Ahok before the governor's election was held, of course, affected the vote acquisition which resulted in Ahok losing the gubernatorial election. The Ahok case above illustrates the success of political identity in winning a political competition (Saputro 2018)

Politics identity, especially religion, never die in the political arena in this country. The momentum of the election for the governor of Jakarta in 2017, is a clear example of justifying this argument. When Religious Identity, appears to be a political force.

The momentum of the Jakarta elections has also displayed several campaign issues that have consumed the energy of the nation, not only the Jakarta public but also the Indonesian peoples, including the case of Surah Al Maidah verse 51 which led to mass mobilization from various regions in the country to come to protest in Jakarta, until its circulation. public opinion 'I am Muslim, I vote for a Muslim leader'. (Sari, 2016)

Political identity (religious equality, equality of ethnicity, equality of regional origin) has always been a threat to the development of democracy in Indonesia, especially in local politics (elections for mayors/regents and governors), political identity has always been a campaign issue and the most effective political marketing to gain voter's sympathy and to take down the opponent. What is interesting is that Pematangsiantar City as the second- 


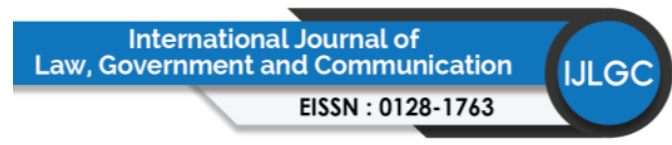

Volume 6 Issue 22 (March 2021) PP. 238-252

DOI 10.35631/IJLGC.6220023

largest cities after Medan in North Sumatra has the jargon "Tolerant City" and got the first rank "Tolerant City" in North Sumatra and "Tolerant City" number three in Indonesia is not spared from political identity in North Sumatra Governor's Election 2018.

Ideally, the people of Pematangsiantar City are not affected by the issue of political identity in the 2018 North Sumatera Governor's Election, because Pematangsiantar City is ranked as the third Most Tolerant City of Indonesian.

The purpose of this study is to measure how much influence of political identity has on the tolerance of the Pematangsiantar City community in the 2018 North Sumatra Governor's Election.

\section{Literature Review}

Two points will be discussed in this research. There are Political Identity and Tolerance City in Governors election 2018 in Pematangsiantar City.

\section{Politic Identity}

Identity can be understood as a social construction. Ethnicity is an expression of past products, the awakening of common origins, social relations, and similarities in cultural values and characteristics such as language and religion. It is further explained that the historical dimension of identity shows that identity is uncertain, not constant, and impermanent, but sometimes changing and can be shaped or constructed. Many factors can influence the construction of identity, such as religion, power, politics, and so on. (Abbas, 2016)

In general, the general theory of political identity and various research results show that two main factors make ethnicity and religion attractive and appear (salient) to be used and influential in the political process. First, when ethnicity and religion are the factors at stake. There is a need to defend or prevent the identity of a group. Second, when the political process takes place competitively. This means that the political process causes the group's identity to face each other and no one is dominant so that it is not clear who will be the winner since long ago. Elections, including local elections, are political processes in which various factors such as identity are at stake. It is up to now how the actors involved in managing issues such as ethnicity and religion are at stake. (Nasrudin, 2018).

According to Manuel Castells (2010), in The Power of Identity, (in Lestari, 2019) identity is a source of self-meaning that emerges and is given by an individual to himself, or from a group of people to their group which is built through the process of individualization. Identity is formed if it is internalized by a community outside of itself. (Lestari, 2019)

Castells divides identity into three categories, namely legitimate identity, resistance identity, and project identity. First, legitimate identity, this identity is used in the process of introducing the dominant institutions of a society to expand and rationalize their domination of social actors. Second, resistance identity, which is an identity that is maintained by fighting to maintain the identity of the stigma of the dominating party. The function of this identity is as resistance and defense against differences in principles in community institutions. The identity of resistance can be understood as an identity that is fought for from beginning to end to gain recognition of that identity from other parties. Third, project identity 


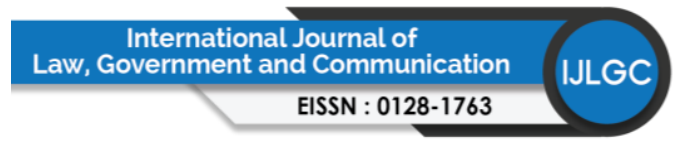

Volume 6 Issue 22 (March 2021) PP. 238-252

DOI 10.35631/IJLGC.6220023

is the act of social actors building a new identity that aims to redefine their position in society by trying to transform from the overall social structure. (Lestari, 2019)

Agnes Heller (in Lestari 2019) defines political identity as politics that focuses on differentiation as the main category that promises freedom, tolerance, and freedom to play (free play), even though it raises patterns of intolerance, violence, and ethnic conflict. political identity can include racism, bio-feminism, environmentalism, and ethnic strife.

Political studies clearly distinguish between political identity and identity politics. Political identity is defined as construction that determines the position of the subject's interests in the bonds of a political community. Meanwhile, political identity is a political mechanism for organizing identity (both political identity and social identity) as a source and means of politics (Muhtar Haboddin, 2012: 119). The study of identity politics includes two recognized identity categories, namely social identity and religious identity as the subject. (Lestari, 2018)

Kopko (2012) in (Saputro 2018) states that religion affects political participation. He gave an example of the teachings of the Mennonite Church, which is to prohibits political activities because of their worldly nature. This resulted in low political activity by the Mennonite Church congregation. The effects and relation between religion and political participation in Indonesia are inevitable. In many cases in Indonesia, religion is used as a tool that positively or negatively generates political participation. (Saputro, 2018)

The demand for identity politics in the context of a power struggle is increasingly open considering the pressure on the partisanship of the majority group in society to always support their political position, especially in heterogeneous societal characteristics with the adoption of strong social stratification will further foster identity politics. (Herdiana, 2019)

There are various points of view that view the phenomenon of identity politics. Pierre Van Den Bergh (1991) and Ubed Abdilah (2002) (in Sari, 2016) explain three theoretical perspectives in studying identity politics, namely: primordialism, constructivism, and instrumentalism. The first approach is the primordial argument that sees religious phenomena in the socio-biological category. This view holds that social groups are characterized by descriptions of territory, religion, culture, language, and social organization as 'given' and cannot be denied. The second approach is constructive which was developed by Frederik Barth. This theory views religious and cultural identity as the result of a complex process, when symbolic boundaries are continually built and constructed, by the benefits of mythology that take place through language and past experiences. The third view, from a theoretical perspective, is that instrumentalists are more concerned with the process of manipulation and political mobilization. According to this view, when these social groups are composed based on the initial attributes of ethnicity such as nationality, religion, race, and language, at that time, the group is mobilizing their interests. (Sari, 2016)

One of the approaches offered by Cohen (Ishiyama, 2013) in the (2018 Sagala and Mukmin) is the instrumentalist approach, which suggests that this approach is a social construction, instrumentalists view the creation of identity as a product of manipulation of cultural symbols and kinship by political actors to obtain political advantage. This approach views ethnicity as the result of a political strategy, which is usually to achieve other goals, such as political power, access to resources, and increasing status and wealth. By interacting and 


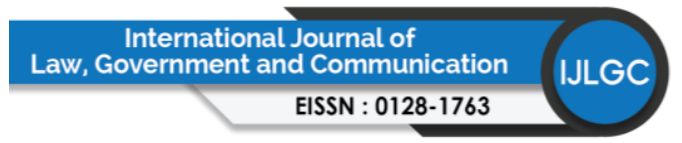

Volume 6 Issue 22 (March 2021) PP. 238-252

DOI 10.35631/IJLGC.6220023

communicating with other ethnic identity groups, a sense of empathy and solidarity will be created so that they form close kinship. So, from the existence of kinship relations, it can also influence the choices of the community. (Sagala and Believer, 2018)

As a pair of candidates, they try to influence society by building kinship ties with each ethnicity to build intimacy, a sense of solidarity, and a sense of closeness to get the attention and trust of the people of each ethnicity which are used to achieve their political interests and goals. The strategy used by building kinship ties is expected to increase the number of votes obtained at the time of the election because the existence of kinship ties between candidates and the community becomes a reason or consideration as voters to provide support for their votes for candidate pairs. So, the ethnic kinship system built into each ethnicity has also succeeded in influencing the choice of voters. The formation of an inter-ethnic kinship system can be a political force because each pair of candidates has a strong support base from each ethnic group as a source of votes. Kinship can be a strong potential vote that a candidate pair has with a system of approach and can attract the attention of voters for voting support. As stated by Buchari (2014) in (Sagala and Mukmin 2018) who sees political identity theoretically as something alive or exists in every ethnicity, where its existence is latent and potential, and at times it can come to the surface as dominant political power. The ethnic diversity that exists in the community in each area, which then forms groups and organizations based on their ethnic similarities such as customs, beliefs, and cultural values of these ethnicities (Sagala and Mukmin, 2018)

\section{City of Tolerance}

Tolerant City in this indexing study is a city that has the following attributes. 1) The city government has regulations that are conducive to the practice and promotion of tolerance, both in the form of planning and implementation. 2) The statements and actions of the city government officials are conducive to the practice and promotion of tolerance. 3) In that city, the level of incidents and acts of violation of freedom of religion/belief is low or nonexistent. 4) The city shows sufficient effort in managing the diversity of religious identities of its citizens. (SETARA, 2018)

More specifically, Brian J. Grim and Roger Finke (2006) compiled three main indicators to measure the level of religious freedom/degree of tolerance of a country. First, favoritism or government privilege of certain religious groups. Second, government regulations limit freedom of religion. Third, social regulations limit freedom of religion. This variable popularized by Grim and Finke was also adopted by Bappenas (National Development Planning Agency) and many other study institutions. In measuring the Tolerant City Index (IKT) in 2018, SETARA Institute also uses the Grim and Finke framework modified with other variables, namely the composition of the population based on religion. The composition of the population is one of the meters in measuring tolerance indicators in city governance because it relates to the level of complexity of diversity governance in cities. (SETARA, 2018)

The 2018's Tolerant City Index Study can take the following conclusions: 1) In 2018, there were 10 cities with the highest tolerance scores, namely sequentially; Singkawang, Salatiga, Pematangsiantar, Manado, Ambon, Bekasi, Kupang, Tomohon, Binjai, and Surabaya. 2) In the same year, on the other hand, there were 10 cities with the lowest tolerance scores, namely in order: Tanjungbalai, Banda Aceh, Jakarta, Cilegon, Padang, Depok, Bogor, 


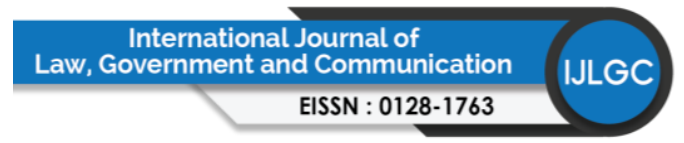

Volume 6 Issue 22 (March 2021) PP. 238-252

DOI 10.35631/IJLGC.6220023

Makassar, Medan, and Sabang. 3) Compared to the Tolerant City Index data in the previous year, there is a significant change in the city group with the highest score. The inclusion of Ambon, Bekasi, Kupang, Tomohon, and Surabaya in the top ten tolerant cities in Indonesia is a new phenomenon in IKT 2018. This means that 50\% of the top 10 ranks are new faces. These cities removed Tual, Kotamobagu, Palu, Tebing Tinggi and Surakarta from the top 10 rankings. 4) Also, juxtaposed with the previous year's IKT data, in general, there was no significant change in composition in the data for the 10 cities with the lowest tolerance index in 2018 unless a very significant change occurred in Tanjungbalai, which this year was ranked 94th (rank 1 bottom ten). Besides, Medan and Sabang were also in the top 10 lowest, ranked 9 and 10). The three cities shifted the position of Yogyakarta, Banjarmasin, and Mataram, which this year came out of the lowest ranks. (SETARA, 2018)

\section{Previous Research}

The Research was conducted by Sayed Muhammad Daulay in 2019 with the title Politics of Identity in the 2018 North Sumatra Governor Election. The findings of this study are: (1) The process of identity politics was carried out by the ERAMAS team (Edy Rahmayadi and Musa Rajeksah) by approaching traditional and religious leaders, while the DJOSS team (Djarot Saiful Hidayat and Sihar Sitorus) only conduct an identity politics process by approaching traditional leaders in various regions; (2) The patterns of identity politics in the ERAMAS team are carried out in the form of activities related to Islam, such as da'wah safaris with Ustadz Abdul Somad, Dzikir Akbar, mosque cleaning car facilities, the dawn movement in a congregation, and officiating, and being involved in traditional activities. Meanwhile, the DJOSS winning team carried out a pattern of activities related to customs in various regions and were involved in customary activities, for religious patterns they only visited religious leaders in the regions. (Daulay. 2019).

The research was conducted by Juhana Nasrudin in 2018 was entitled: Identity Politics and Political Representation (Case Study in the 2018-2022 DKI Regional Election). The results show that the political orientation of identity and political representation affects the democratic process in the 2018-20122 DKI regional election cases (Nasrudin, 2018)

The research was conducted by Ivan Dei Sagala and Budi Ali Mukmin in 2018 with the title: Ethnic Identity Politics in the Pilkada Election for Mayor and Deputy Mayor of Binjai in 2015 ". The results showed that the involvement of ethnicity influences in terms of being a source of the voice. Ethnic identity relations are a consideration in determining voter choices. Candidate pairs can exploit the existence of ethnic groups by using approaches as a place or basis for gaining votes. The existence of kinship between ethnic groups that occurs from this approach is also the reason for the community to choose. Also, there is support from ethnicity such as socializing again and inviting families to choose one candidate pair. Meanwhile, the existence of these ethnic identities becomes a political force to get votes. (Sagala and Believer, 2018)

Further research on identity politics was carried out by Saradi Wantona, Rilus A. Kinseng, and Sofyan Sjaf in 2018 with the title Practices of Identity Politics in the Local Political Dynamics of Gayo Communities. The results showed that first; The dominant capital played by political actors in local political contestation is the political capital, social capital, and economic capital. Second, the practice of identity politics in the Gayo community which propagates the term Uken -Toa is carried out by political actors, while at the grassroots the 


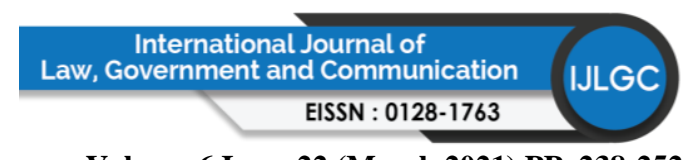

Volume 6 Issue 22 (March 2021) PP. 238-252

DOI 10.35631/IJLGC.6220023

identity sentiment between Uken and Toa is still ongoing and so strong. Third, the habitus of political actors is influenced by three things, history, religion, and culture. That way, the conditions of habitus that played a role in political contestation were the history of the formation of the identity of Uken and Toa in the past and the political influence of fighting against each other by the Dutch colonialists. (Wantona, 2018)

The novelty in this study is the influence of identity politics on voter behavior in Pematangsiantar City in the 2018 North Sumatra Governor Election, which examines the relationship between identity politics in a community known as a "tolerant" city. This study is different from previous studies due to the influence of identity politics in the community of Pematangsiantar City which is known as a "Tolerant" City.

\section{Method Research}

The research approach that will be used in this research is quantitative with the type of correlation that aims to calculate the magnitude of the influence of identity politics on the voter behavior of the Pematangsiantar City community in the 2018 North Sumatra Governor and Deputy Governor Election. The research locations are in 8 sub-districts and 53 villages in Pematangsiantar City with a sample of 399 people. The data analysis technique was performed using the Spearman correlation

\section{Result and Discuss.}

Choosing behavior is a complex phenomenon. The decision to choose is determined by many factors. A candidate who comes from a certain primordial identity group may not necessarily be able to attract a majority in his group. This can happen because, apart from the identity factor, voters also consider other factors, especially the personal quality of the candidate. In essence, local political dynamics often open up space for the mobilization of identity politics. In general, this study has found empirical evidence that religion and ethnicity which fuel identity politics are important factors in regional head elections. (Muhtadi, 2018)

Ideally, the people of Pematangsiantar City are not affected by the issue of identity politics in the 2018 North Sumatra Governor Election, because by looking at the results of research (SETARA, 2018) in measuring the Tolerant City Index (IKT) in 2018 in measuring the Tolerant City Index (IKT) which is also uses three main indicators to measure the level of freedom of religion/degree of tolerance of a country. Namely: First, favoritism or government privilege of certain religious groups. Second, government regulations limit freedom of religion. Third, social regulations that limit religious freedom which is popularized by specifics, Brian J. Grim and Roger Finke (2006), the people of Pematangsiantar City will not be affected by Identity Politics both in their voting behavior and social tolerance in the 2018 North Sumatra Governor Election. 


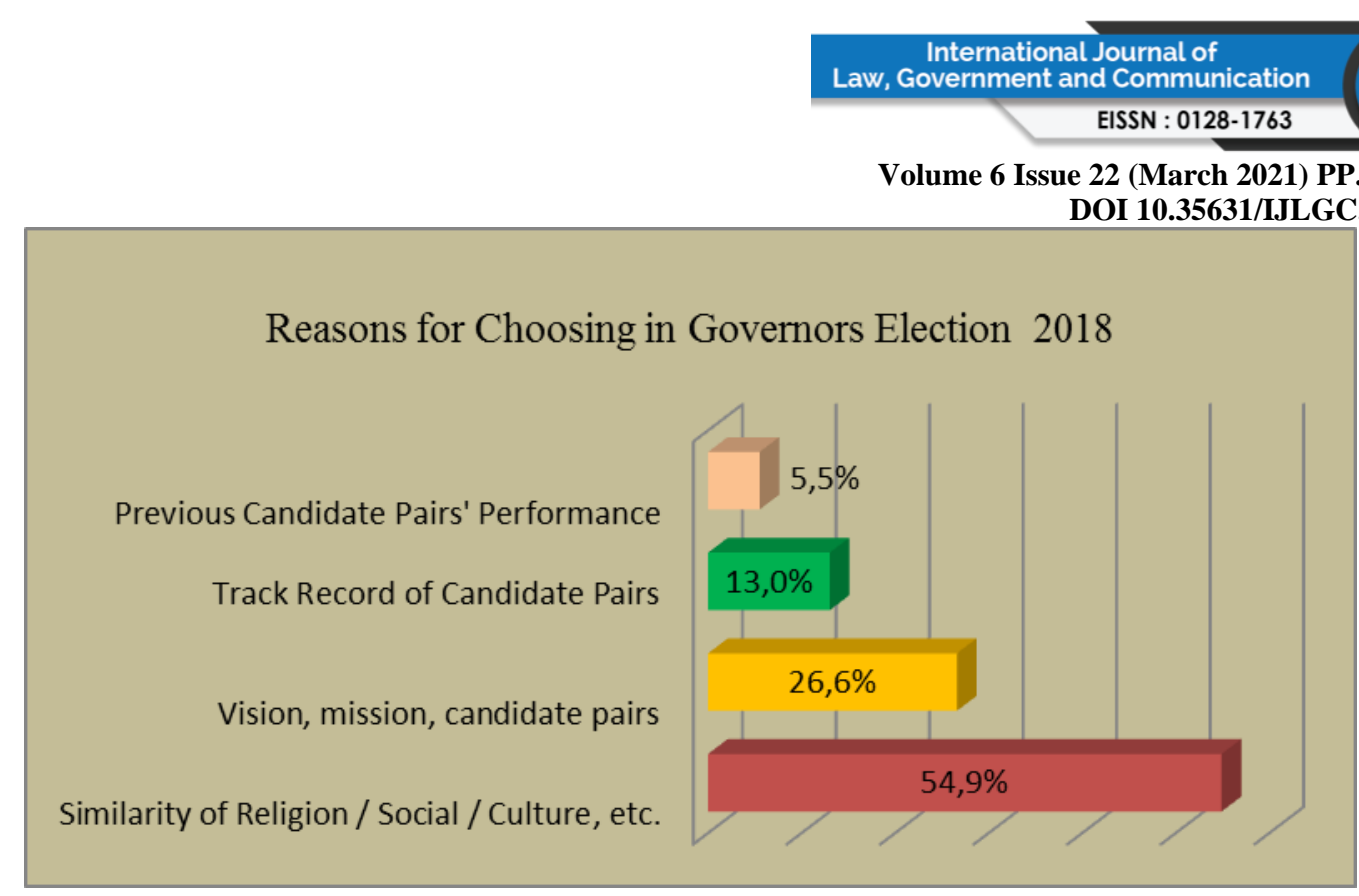

Reasons for Chosing in Governors Election 2018

It can be seen clearly that the choice of Pematangsiantar City community in the 2018 North Sumatra Governor Election cannot be separated from Identity Politics, namely due to religious similarities. Interestingly, in the case of the 2018 North Sumatra Governor Election, the candidate pair Edy-Musa Rajeksah is Muslim, while the Djarot-Sihar Sitorus pair is Muslim-Christian, especially in Pematangsiantar City, where the majority of the people are Christian as much as 55\%, of course, vote for the Djarot's pair Sihar Sitorus. The similarity of religion cannot be denied in the choice of identity politics of the people of Pematangsiantar City in the 2018 North Sumatra Governor Election. Voters in Pematangsiantar City are divided between the voters for the Edy-Ijeck and Djarot-Sihar pairs where Edy and Djarot are Muslims, only Sihar Sitorus is a Christian. , and of course get full support from voters who are Christian in Pematangsiantar City, which is the majority religion in Pematangsiantar City. It is undeniable that the similarity of religion and political marketing brought by candidate pairs in the North Sumatra Governor's Election campaign clarified identity politics in the 2018 North Sumatra Governor election in Pematangsiantar City community which is famous for the jargon of the city of highest tolerance in North Sumatra and number third-highest in Indonesia. Like it or not, identity politics cannot be separated from the local politics of the election for the Governor of North Sumatra in 2018, even though it is faced with people who live in the city, which is known to be tolerant, Pematangsiantar City.

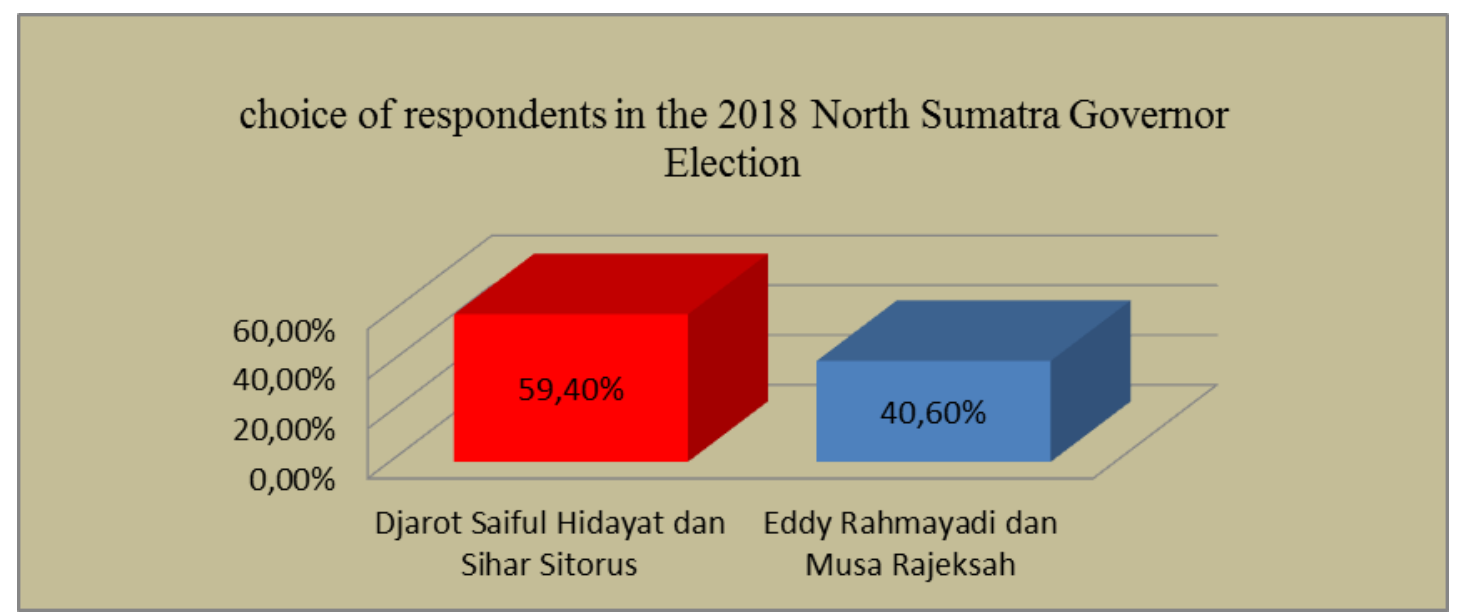

Choice of respondents in the 2018 North Sumatra Governor Election 


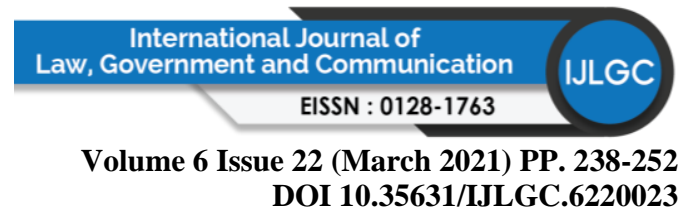

This is important and attractive to political parties with pairs of candidates in local politics, either in the election for mayor/regent or governor election. Identity politics cannot be separated from local politics, of course, must be understood in our democracy in Indonesia, especially in local politics, that the political culture of Indonesian society cannot be separated from identity politics which is strongly embedded in people's choices. Even the most tolerant city in North Sumatra cannot be separated from this identity politics, and according to researchers, this is not a big problem in a democratic climate that gives citizens the freedom to be elected and to vote in every local political election. This clear thread between identity politics and local politics is expected to be able to be understood and managed by political party cadres, and political party administrators so that they can present candidate pairs in local politics (election for mayors/regents and elections for governors) who can harmonize local politics and identity politics. . Identity politics is should not and does not conflict with the climate of democracy in Indonesia, identity politics is legally permissible, this must be understood by political party administrators and cadres of political parties or people outside political parties (political party cadres) who wish to advance as a candidate for regional head either mayors/regents and governors in the regions. Thus, political party administrators who will carry candidate pairs in local politics (election of mayors/regents and governors) in the regions can display cadres or figures that are thick with regional identities from religion, ethnicity, regional origin, and of course have high capability and electability. in the community and a good track record and performance. Likewise, cadres and non-cadres of political parties who want to run as candidate pairs so that they are self-aware and pay attention to identity politics as the basic provisions in local political battles (elections for mayors/regents and governors) in the regions.

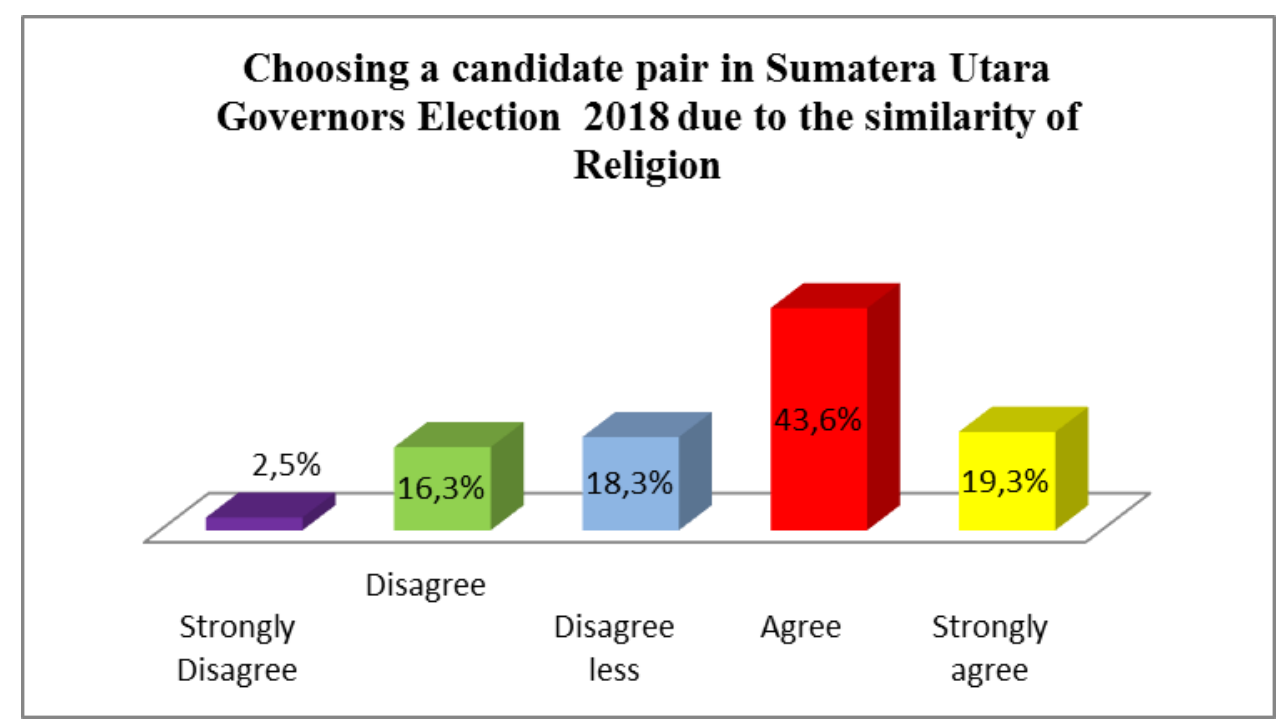

\section{Choosing a candidate pair Sumatera Utara Governor Election 2018 due to the similarity of Religion}

In Pematangsiantar City, the pair number two Djarot - Sihar Sitorus received about $68.604 \%$ (percent) of votes, then the pair number one Edy Rahmayadi - Musa Rajeckshah received about $41.551 \%$ (percent) votes, this is directly proportional to the majority of Christianity as religion The majority of the community's religion in Pematangsiantar City is 55\%, of course, identity politics with the same religion that Sihar Sitorus has as a partner of Djarot Saiful Hidayat benefits in Pematangsiantar City. Thus the identity politics of religious equality has Copyright (C) GLOBAL ACADEMIC EXCELLENCE (M) SDN BHD - All rights reserved 
Volume 6 Issue 22 (March 2021) PP. 238-252

DOI 10.35631/IJLGC.6220023

an effect on the choices of the Pematangsiantar City community in the 2018 North Sumatra Governor's Election.

\section{Religion Responden * Choice in Sumatera Utara Governor Election 2018 Crosstabulation}

Count

\begin{tabular}{|c|c|c|c|c|}
\hline & \multicolumn{2}{|c|}{$\begin{array}{c}\text { Sumatera Utara Governor } \\
\text { Election } 2018\end{array}$} & \multirow[b]{2}{*}{ Total } \\
\hline & & $\begin{array}{l}\text { Djarot Saiful } \\
\text { Hidayat dan } \\
\text { Sihar Sitorus }\end{array}$ & $\begin{array}{c}\text { Eddy } \\
\text { Rahmayadi } \\
\text { dan Musa } \\
\text { Rajeksah } \\
\end{array}$ & \\
\hline \multirow{4}{*}{$\begin{array}{l}\text { Religion } \\
\text { Responden }\end{array}$} & of Protestan & 217 & 47 & 264 \\
\hline & Islam & 20 & 98 & 118 \\
\hline & Katolik & 15 & 0 & 15 \\
\hline & Budha & 2 & 0 & 2 \\
\hline Total & & 254 & 145 & 399 \\
\hline
\end{tabular}

Based on the table Respondent Religion * Choice in the 2018 PILGUBSU Crosstabulation can be seen clearly from the 264 Protestant respondents who mostly chose pair number two, namely Djarot Saiful Hidayat-Sihar Sitorus, as many as 217 people while Christian respondents who chose Eddy Rahmayadi -Musama Rajeksah, are 47 people. This is clear because one of the candidate pairs, Sihar Sitorus, is a Protestant and has the full support of the Pematangsiantar City community, especially those who are Protestants. Meanwhile, as many as 118 Muslim respondents, the majority chose the Eddy Rahmayadi-Musa Rajeksah pair, as many as 98 people and only 20 people chose the Djarot Saiful Hidayat-Sihar Sitorus pair. Hidayat is also a Muslim, but his partner Sihar Sitorus is a Protestant. Likewise, respondents who were Catholic and Buddhist all chose the Djarot Saiful Hidayat-Sihar Sitorus pair. This explains that identity politics with religious equality cannot be separated from local politics and affects the choice of the people of Pematangsiantar City, which is known as a Tolerant City in North Sumatra and the number third Tolerant City in Indonesia in the 2018 North Sumatra Governor's Election 
Volume 6 Issue 22 (March 2021) PP. 238-252 DOI 10.35631/IJLGC.6220023

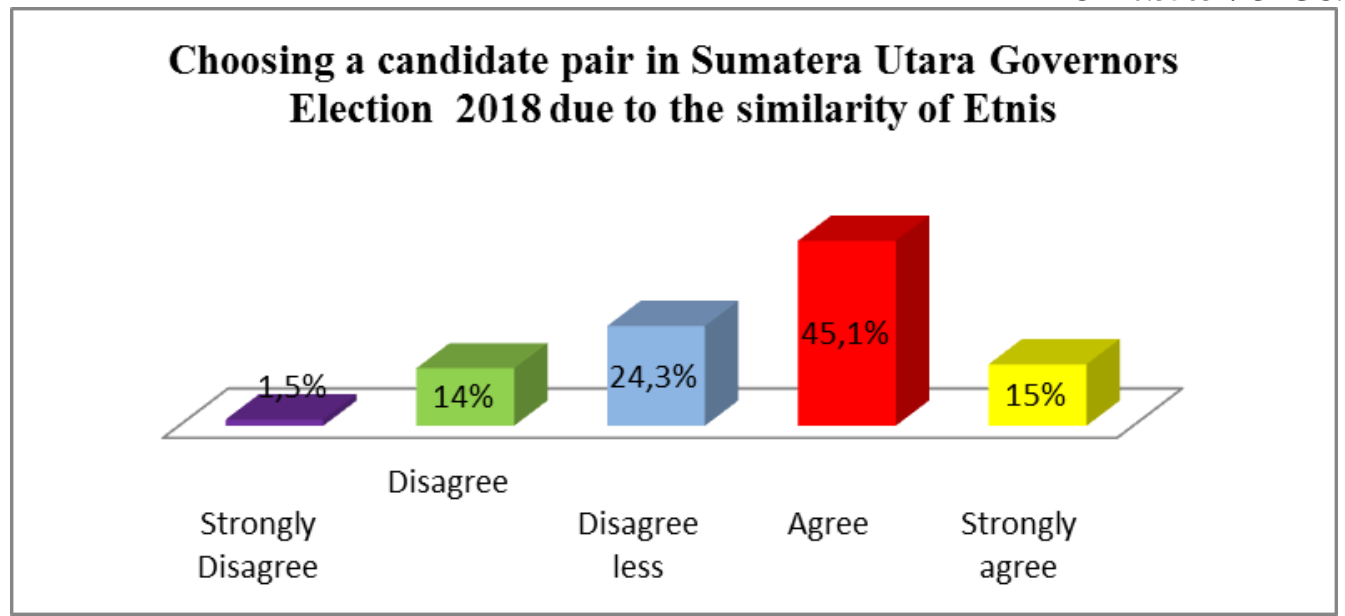

\section{Choosing A Candidate Pair In Sumatera Utara Governors Election 2018 Due To The Similarity Of Etnic}

The figure on the top explains the identity politics of ethnic equality affecting the choice of the Pematangsiantar City community in local politics for the 2018 North Sumatra Governor Election. This is because Djarot Saiful Hidayat is originally Javanese from Solo, even though Djarot Saiful Hidayat is not Javanese born in Sumatra (pujakesuma), but Djarot Saiful Hidayat is the only Javanese in the 2018 North Sumatra Governor's Election.

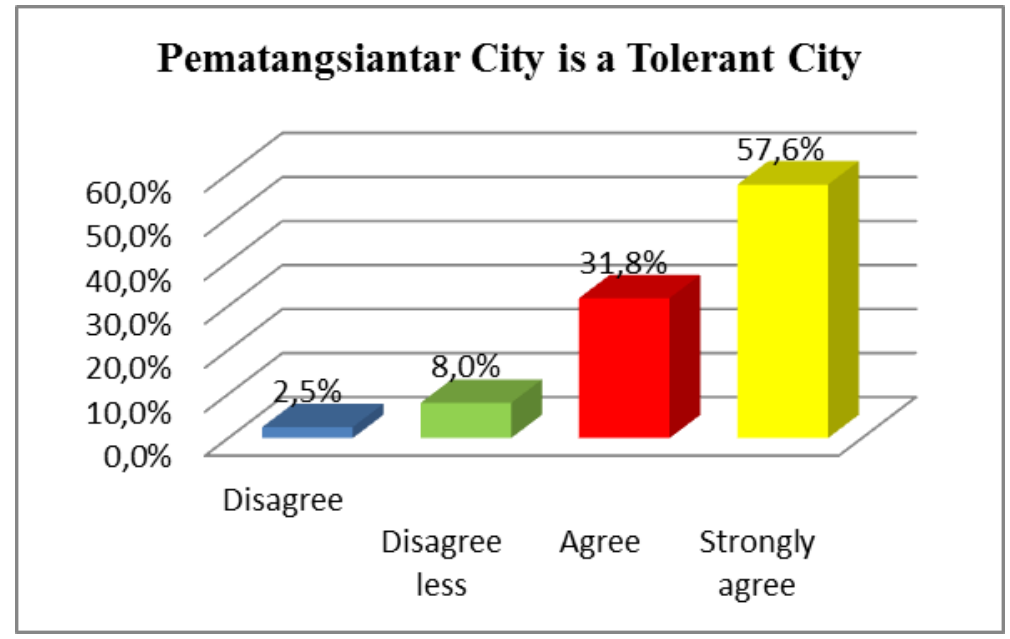

Pematangsiantar City is a Tolerant City

Tolerant city in North Sumatra and tolerant city number third in Indonesia are strongly attached to Pematangsiantar City. Religious tolerance, social tolerance, social tolerance are very strong in the social life of the Pematangsiantar City community, however, this tolerance did not occur in local political choices, namely, the 2018 North Sumatra Governor Election which presented candidate pair Edy Rahmayadi-Musa Rajeksah and pair Djarot Saiful Hidayat-Sihar. Sitorus. The results of the calculation of Pematangsiantar City KPUD pair Djarot Saiful Hidayat-Sihar Sitorus received 2,424,960 votes or 42.42\%. In Pematangsiantar City, pair number two Djarot - Sihar Sitorus received about $68.604 \%$ (percent) of votes, then pair number one Edy Rahmayadi - Musa Rajeckshah received about $41.551 \%$ (percent) votes which were influenced by the similarity of religion and ethnicity in Sumatra Utara Governor Election 2018. 
The tolerance of Pematangsiantar City community is high so it is not affected by the issue of religious campaigns at Governors Election in 2018

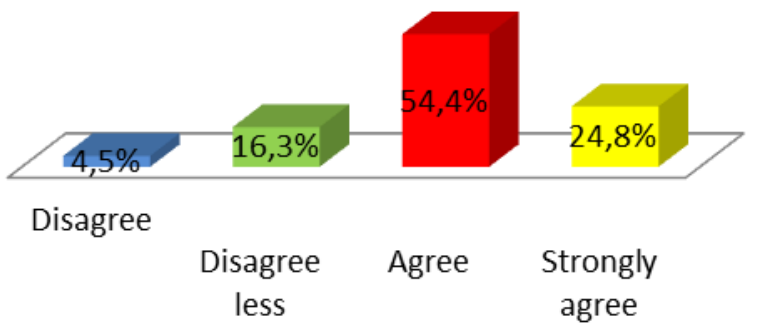

The Tolerance Of Pematangsiantar City Community Is High So It Is Not Affected By The Issue Of Religious Campaigns At Governors Election In 2018

The figure states that the tolerance of the people of Pematang Siantar City is high so that it is not affected by the issue of campaigning for religious differences resulting in divisions in people's lives during the 2018 North Sumatra Governor's Election.

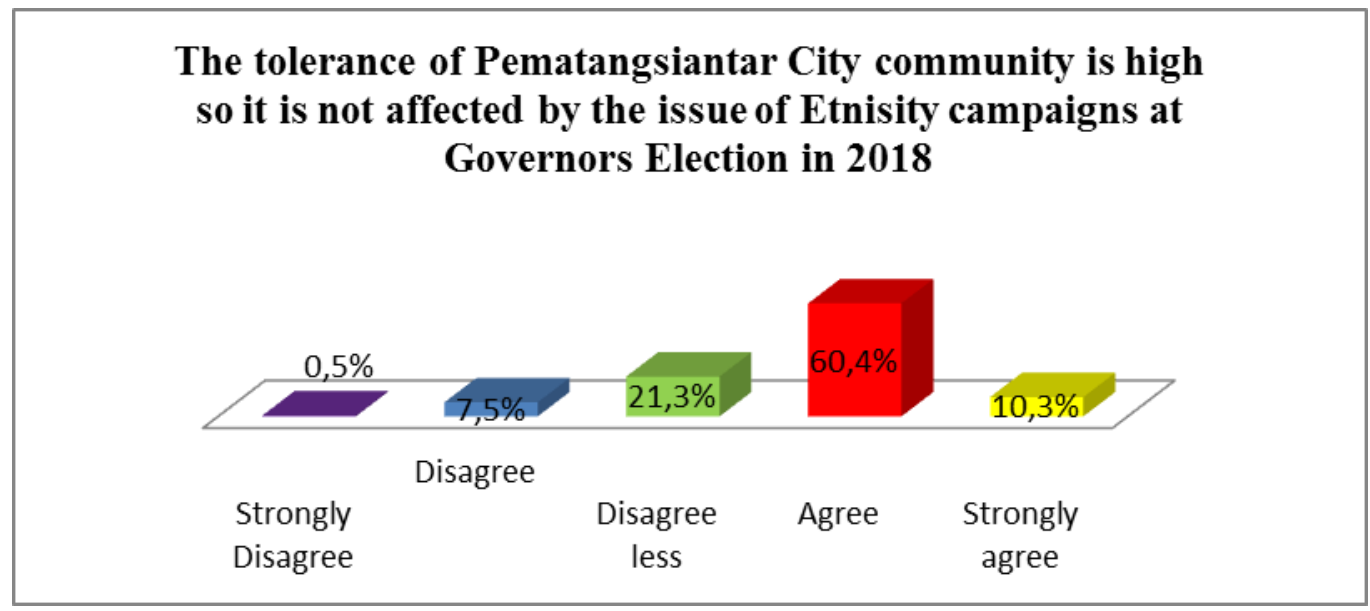

The Tolerance Of Pematangsiantar City Community Is High So It Is Not Affected By The Issue Of Ethnicity Campaigns At Governors Election In 2018

Tolerance of Pematangsiantar City community is also seen from not being influenced by the issue of ethnicity campaign in the North Sumatra Governor Election in the year, no friction occurs among the people of Pematangsiantar City with issues of ethnicity, although identity politics still feels thick in Pematangsiantar City society, however, respectively the camp can still hold back and there is no social friction due to different choices in the 2018 North Sumatra Governor Election. 
Volume 6 Issue 22 (March 2021) PP. 238-252 DOI 10.35631/IJLGC.6220023

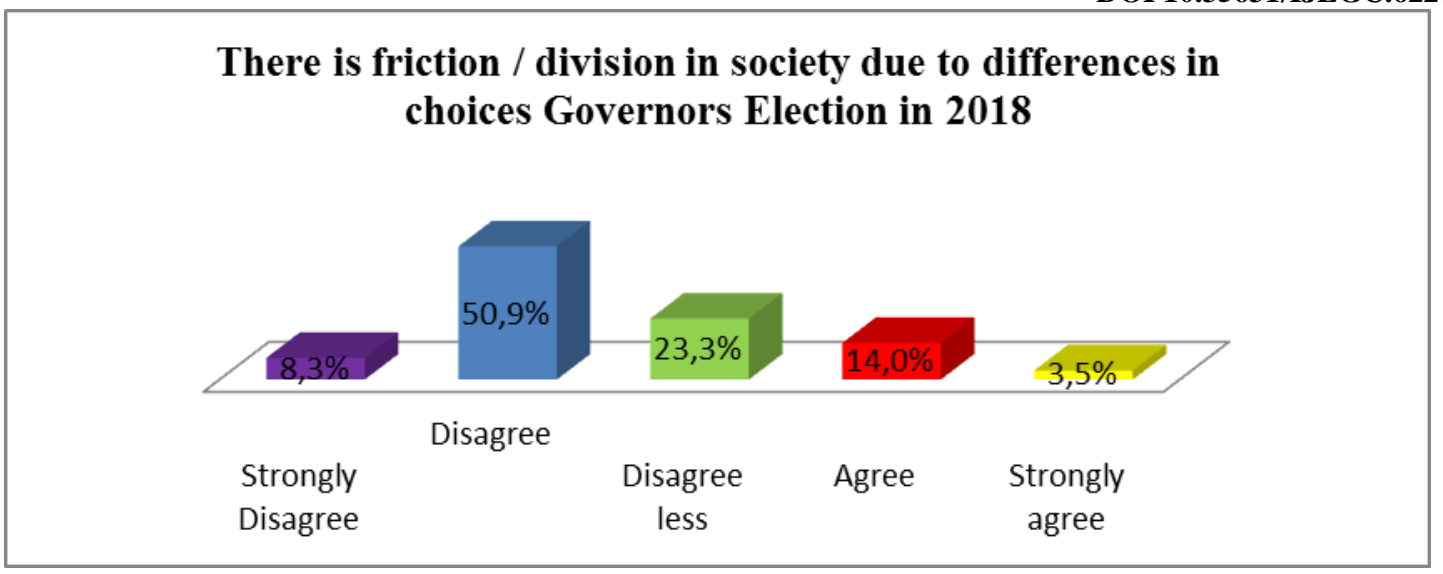

\section{There Is Friction / Division In Society Due To Differences In Choices Governors Election In 2018}

The figure on the top shows Pematangsiantar City as a tolerant city, this can be seen from the absence of divisions in the Pematangsiantar City community due to different choices in the 2018 North Sumatra Governor Election. Even though there are still differences of opinion and differences in choice but there are no divisions in the community, let alone until they occur. chaos and Pematangsiantar City have proven to be a tolerant city with differences of opinion and different choices in the 2018 North Sumatra Governor Election.

\section{The Correlation of Identity Politics Against Tolerance of Pematangsiantar City Community in Sumatera Utara Governor Election 2018 Correlations}

\begin{tabular}{|c|c|c|c|c|}
\hline & & & $\begin{array}{l}\text { Politic } \\
\text { Identity }\end{array}$ & $\begin{array}{c}\text { Community } \\
\text { tolerance in } \\
\text { Pematangsian } \\
\text { tar City } \\
\end{array}$ \\
\hline \multirow[t]{6}{*}{ Politic Identity } & \multirow[t]{3}{*}{ Politic Identity } & $\begin{array}{l}\text { Correlation } \\
\text { Coefficient }\end{array}$ & 1,000 &,$- 120^{*}$ \\
\hline & & Sig. (2-tailed) & & ,017 \\
\hline & & $\mathrm{N}$ & 399 & 399 \\
\hline & $\begin{array}{l}\text { Community } \\
\text { tolerance in }\end{array}$ & $\begin{array}{l}\text { Correlation } \\
\text { Coefficient }\end{array}$ &,$- 120^{*}$ & 1,000 \\
\hline & \multirow{2}{*}{$\begin{array}{l}\text { Pematangsian } \\
\text { tar City }\end{array}$} & Sig. (2-tailed) &, 017 & \\
\hline & & $\mathrm{N}$ & 399 & 399 \\
\hline
\end{tabular}

*. Correlation is significant at the 0.05 level (2-tailed).

From the table above, it can be seen that the Spearman correlation coefficient is -.120. This means that the identity politics variable has a weak correlation with the tolerance of the Pematangsiantar City community in the 2018 North Sumatra Governor Election, which is 0.120 or very weak and negative. Correlation has two-tailed (2-tailed) possibilities. 


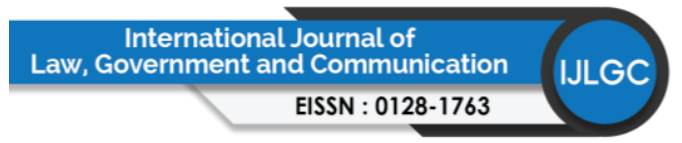

Volume 6 Issue 22 (March 2021) PP. 238-252

DOI 10.35631/IJLGC.6220023

Seeing the direction (type) of the relationship between the identity politics variable and the tolerance of the people of Pematangsiantar City in the 2018 North Sumatra Governor Election, the correlation coefficient in the table above is negative, namely -0.120 , so that the relationship between the two variables is unidirectional. Thus, it means that the higher it is identity politics in the 2018 North Sumatra Governor Election, the socially tolerant of the Pematangsiantar city community will below. Seeing the significance of the relationship between the two variables. Based on the output in the table above, it is known that the significance value or Sig. (2-tailed) of 0.017 . because the significant number is $0.017<0.05$. So there is a significant relationship between the identity politics variable and the tolerance of the Pematangsiantar City community in the 2018 North Sumatra Governor Election. This means that the relationship between the two variables, namely the politics of identity and tolerance of the people of Pematangsiantar City in the 2018 North Sumatra Governor Election, is two-way or mutually influencing. The conclusion is that there is a correlation between the identity politics variable and the tolerance of the Pematangsiantar City community in the 2018 North Sumatra Governor Election which is very weak, negative, significant, and two-way.

\section{Conclusion}

Political Identity is inseparable from the community which is known as the city jargon "Tolerant". Although there is a relationship between political identity and the tolerance of the Pematangsiantar City community, the value of this relationship is weak. The correlation between the identity politics variable and the tolerance of the Pematangsiantar City community in the 2018 North Sumatra Governor Election (-0.120) is very weak, negative, significant, and a two-way significance value or Sig. (2-tailed) of 0.017 . because the significant number is $0.017<0.05$. The meaning of identity politics affects the tolerance of the Pematangsiantar City community in the 2018 North Sumatra Governor Election.

\section{Acknowledgments}

Researchers would like to thank the Research Institute at the Universitas Sumatera Utara for financing this research by agreement/contract Number: 32 / UN5.2.3.1. / PPM / SPPTALENTAUSU / 2020. So that this research can be completed properly.

\section{References}

Abbas, M.R. (2016). "Ruang Publik dan Ekspresi Politik Identitas: Studi Tentang Pergulatan Identitas Ke-Papuaan di Yogyakarta) Jurnal Society, Volume VI, Nomor I, Juni 2016

Chin, J. L. (2011). Women and Leadership: Transforming Visions and Current Contexts. Forum on Public Policy: A Journal of the Oxford Round Table, (2), 1-12.

Creswell, J.W. (2018) Qualitative Inquiry \& Research Design-Choosing among Five Approaches. 4nd Edition, London: Sage Publications,

Daulay, S.M. (2019). Politik Identitas pada Pemilihan Gubernur Sumatera Utara Tahun 2018. Jurnal: Jurnal Administrasi Publik : Public Admnistration Journal, 9 (1) Juni 2019. ISSN 2088-527X (Print) ISSN 2548-7787 (Online), DOI: 10.31289/jap.v9i1.2230

Heridiana, D. (2019). Konstruksi Politik Identitas Melalui Nilai-Nilai Islam Dalam Pemilihan Kepala Desa di Kabupaten Bandung Barat”. Jurnal: Jurnal Tapis: Jurnal Teropong Aspirasi Politik Islam 15 (2) 2019

Hutabarat, (2018). 94 Daftar Kota Toleransi Tertinggi dan Terendah Versi Setara Institute. Dapat diakses di https://www.liputan6.com/news/read/3802166/94-daftar-kota- 
Volume 6 Issue 22 (March 2021) PP. 238-252 DOI 10.35631/IJLGC.6220023

toleransi-tertinggi-dan-terendah-versi-setara-institute. Di akses pada 20 Februari 2020. Pukul 18.30 W.I.B

Lestari, D. (2019). PILKADA DKI Jakarta 2017: Dinamika Politik Indentitas di Indonesia Jurnal: SIMULCARA, Volume 2, Nomor 1 Juni 2019

Lestari, Y.S (2018). Politik Identitas di Indonesia: Antara Nasionalisme dan Agama. Jurnal: Journal of Politics and Policy Volume 1, Number 1, Desember 2018

KPU.go.id. (2018). Hasil Perhitungan Suara Pilgubsu 2018 di Kota Pematangsiantar dapat di akses pada laman https://infopemilu.kpu.go.id/pilkada2018/pemilih/dps/1/Sumatera\%20utara/Kota\%2

Muhtadi, B. (2018) "Politik Identitas dan Mitos Pemilih Rasional". Jurnal: MAARIF Vol. 13, No. 2 - Desember 2018

Nasrudin, J. (2018). “ Politik Identitas dan Representasi Politik. (Studi Kasus pada Pilkada DKI Periode 2018-2022). Jurnal: Hanifya: Jurnal Dtudi Agama-Agama. Volum 1 Nomor 1 Tahun 2018: 34-37. ISSN 2089-8835

Pematangsiantar.Mustanir A, dan Jaya I. (2016) "Pengaruh Kepemimpinan Dan Budaya Politik Terhadap Perilaku Pemilih Towani Tolotang Di Kecamatan Maritengngae Kabupaten Sidenreng Rappang" Jurnal Politik Profetik Volume 04, No. 1 Tahun 2016, dapat di akses pada laman: http://journal.uinalauddin.ac.id/index.php/jpp/article/download/2741/2584, di akses pada 3 Februari 2019 pukul 10.00 W.I.B

Saputro, A. (2018). “ Agama dan Negara: Politik Identitas Menuju Pilpres 2019. Jurnal Asktetik. Vol 2 No. 2 Desember 2018.

Sari, E. (2016). "Kebangkitan Politik Identitas Islam Pada Arena Pemilihan Gubernur Jakarta". Jurnal KRITIS: Jurnal Ilmu Sosial dan Ilmu Politik Universitas Hasanuddin. Volume 2 Nomor 2. Desember 2016

Setara. I (2018). PRESS RELEASE: INDEKS KOTA TOLERAN (IKT) TAHUN 2018 diakses di http://setara-institute.org/indeks-kota-toleran-ikt-tahun-2018/ di aksen pada: 20 Februari 2020, pukul 19.30 W.I.B

Wantona. S., Kinseng, R.A dan Sjaf. S. (2018). Praktik Politik Identitas Dalam Dinamika Politik Lokal Masayarakat Karo. Jurnal: Sodality: Jurnal Sosiologi Pedesaan. Vol 6 No 1 April 2018. 